\title{
The effect of training and the Alka competition on oxidative stress and metabolic parameters in two horse breeds
}

\author{
Jasna Aladrović1*, Blanka Beer Ljubić1, Nikica Prvanović Babić2, \\ Lana Vranković́ ${ }^{1}$ Edita Klepo ${ }^{3}$, Lucija Iličićc ${ }^{3}$, Stjepan Šimundža \\ Lada Radin ${ }^{1}$, Jelena Šuran ${ }^{5}$, Josip Kos ${ }^{6}$, and Zvonko Stojević ${ }^{1}$ \\ ${ }^{l}$ Department of Physiology and Radiobiology, Faculty of Veterinary Medicine, University of Zagreb, \\ Zagreb, Croatia \\ ${ }^{2}$ Clinic for Reproduction and Obstetrics, Faculty of Veterinary Medicine, University of Zagreb, \\ Zagreb, Croatia \\ ${ }^{3}$ Student of integrated undergraduate and graduate study of veterinary medicine, Faculty of Veterinary \\ Medicine, University of Zagreb, Zagreb, Croatia \\ ${ }^{4}$ Viteško alkarsko društvo - Alkarska ergela d.o.o., Sinj, Croatia \\ ${ }^{5}$ Department of Pharmacology and Toxicology, Faculty of Veterinary Medicine, University of Zagreb, Croatia \\ ${ }^{6}$ Clinic for Surgery, Orthopedics and Ophthalmology, Faculty of Veterinary Medicine, University of Zagreb, \\ Zagreb, Croatia
}

\begin{abstract}
ALADROVIĆ, J., B. BEER LJUBIĆ, N. PRVANOVIĆ BABIĆ, L. VRANKOVIĆ, E. KLEPO, L. ILIČIĆ, S. ŠIMUNDŽA, L. RADIN, J. ŠURAN, J. KOS, Z. STOJEVIĆ: The effect of training and the Alka competition on oxidative stress and metabolic parameters in two horse breeds. Vet. arhiv 88, 295-308, 2018.

\section{ABSTRACT}

The aim of this study was to investigate the effects of training and the Alka competition upon the activity/ concentrations of antioxidative and muscle enzymes and metabolic parameters, as well as their correlations, in the serum of Thoroughbred $(\mathrm{TH})$ and Croatian Warmblood (CWH) horses. The experiment was carried out on nine THs and seven CWHs. Blood samples were collected 30, 21 and 14 days before the Alka competition, immediately after the competition, and 7 days after. Serum concentrations of malondialdehyde (MDA), the activity of glutathione peroxidase (GSH-Px), total superoxide dismutase (SOD), paraoxonase 1 (PON 1), creatine kinase (CK), aspartate aminotransferase (AST) and lactate dehydrogenase (LDH) were determined, as well as glucose, triglyceride, nonesterified fatty acids (NEFA), total cholesterol and high density lipoprotein cholesterol (HDL-C) concentrations. Serum MDA concentrations in both breeds were significantly higher 30 days before the Alka than immediately after the race. Serum activity of SOD in TH was significantly higher 21 days before the Alka compared to the values after 7 days of rest. Serum NEFA concentration in TH was
\end{abstract}

\footnotetext{
*Corresponding author:

Assoc. Prof. Jasna Aladrović, PhD, Department of Physiology and Radiobiology, Faculty of Veterinary Medicine, University of Zagreb, Heinzelova 55, Zagreb, Croatia, Phone: +385 12390 173; Fax: +385 12441 390; E-mail: jasna.aladrovic@vef.hr
} 
also significantly higher 30 days before the Alka and immediately after the race, compared to concentrations 7 days after the race. Triglyceride concentrations in TH were significantly higher after 7 days of rest compared to 30 and 14 days before the race. The PON1/HDL-C ratio was significantly higher in $\mathrm{CWH}$ than in $\mathrm{TH}$ serum 21 days before the Alka. MDA values were significantly lower in CWH than in TH 14 days before the Alka. Significantly higher AST and CK serum activity was determined in CWH than in TH 30 days before Alka. Triglyceride concentrations 21 days before the competition were significantly higher in $\mathrm{CWH}$ compared to values in $\mathrm{TH}$. The results indicate the oxidative stability of horse serum during training and competition, breed differences during training and competition, and a shift in fat metabolism due to the elevated energy needs.

Key words: horses; exercise; antioxidative enzymes; oxidative stress; metabolic biomarkers

\section{Introduction}

Physical activity and exercise increase oxygen uptake, which leads to enhanced reactive oxygen species (ROS) generation, and possibly oxidative stress (LI, 2008). The main source of unpaired electrons is the mitochondrial electron-transport chain (DI MEO and VENDITTI, 2001), with myocytes being especially abundant in the mitochondria (GUYTON and HALL, 2016). Exercise-induced stress leads to myocyte damage caused by oxidative damage to cell membranes and cytoplasm organelles. The intensity of oxidation and cell damage can be evaluated by measuring the concentrations of oxidized lipids, amino acids and nucleic acids, changes in antioxidative enzymatic activity or the concentrations of non-enzymatic antioxidative compounds. Measurement of the intensity of lipid peroxidation is the most common method for determining the degree of oxidative damage (AYALA et al., 2014).

Trained animals and humans are thought to be exposed to oxidative stress during training programs (POWERS and JACKSON, 2008) and competition (PEPE et al., 2009) and are therefore in need of adequate antioxidative protection in order to eliminate the increased amounts of oxidants (SOFFLER, 2007).

Studies in humans and animals have demonstrated that strenuous and prolonged low- to medium-intensity exercise induces oxidative stress (MARLIN et al., 2002; HARGREAVES et al., 2002; SOFFLER, 2007; POWERS and JACKSON, 2008; STEINBACHER and ECKL, 2015). The extent of muscle tissue damage varies in different studies, which, even in studies with similar experimental design, could be ascribed to differences in animal management, individual differences, fitness or the analytical methods used.

Changes in oxidant-antioxidant balance may occur during or immediately after exercise, but also after the animals have rested. Antioxidant capacity is thought to be enhanced in well-trained animals (POWERS and JACKSON, 2008). Both prolonged aerobic and anaerobic training increases the activity of antioxidant enzymes in horse blood (SOFFLER, 2007; LI, 2008). The oxidant-antioxidant balance depends on age, sex and breed (KIRSCHVINK et al., 2008). 
Increased peroxidation due to high ROS concentrations in muscle cell mitochondria leads to damage to the myocyte membranes (ART and LEKEUX, 2005). Therefore, the enzymatic activity of creatine kinase (CK), aspartate aminotransferase (AST) and lactate dehydrogenase (LDH) is elevated (HARGREAVES et al., 2002; LI et al., 2012).

Controlled training may be one of the ways to increase the antioxidant defence in the tissues of subjects undergoing physical exercise. CHIARADIA et al. (1998) found that lipid peroxidation following intensive exercise is insufficient to cause the significant lysis of horse skeletal muscle cells, as demonstrated by the absence of changes in the CK and LDH-4 activity in the blood. They found, however, that acute exercise generates free radicals with the subsequent lipid peroxidation, demonstrated by the increase in both malondialdehyde (MDA) and glutathione contents in the plasma.

Strenuous exercise mobilizes stored fat to be used as a fuel. During prolonged exercise energy needs are met through lipolysis and, to a lesser extent, gluconeogenesis (GUYTON and HALL, 2016). Therefore, changes in blood lipid concentrations serve as an indicator of changes in energy metabolism (VERMEULEN at al., 2017). Furthermore, strenuous exercise in racehorses elevates blood NEFA, triglyceride and cholesterol concentrations, in contrast to riding horses, due to the better adaptation of riding horses to lipid mobilization (LI et al., 2012).

This experiment was conducted during preparations for the Alka competition, after the race, and after 7 days of rest. The Sinjska alka is a jousting competition where a rider has to race down a course $160 \mathrm{~m}$ long on a horse at full gallop, to hit the centre of a small iron circle called an alka, using a spear. This competition commemorates Croatia's Venetian victory over the Ottomans and has been included in the UNESCO Intangible Cultural Heritage Lists. The stress that horse undergoes is both physical and psychological due to the atmosphere of the racecourse and audience. The purpose of this study was to investigate how an intensive 30 day training period including physical and psychological preparation, influenced the activity/concentrations of antioxidative enzymes, MDA, muscle enzymes and metabolic parameters as well as their correlations, in the serum of Thoroughbred (TH) and Croatian Warmblood (CWH) horses.

\section{Materials and methods}

Animals, husbandry and nutrition. The study protocol was approved by the Ethics Committee of the Faculty of Veterinary Medicine (251-61-01/139-11-10). During 2011, training started for 32 animals of six different breeds. They were selected to reduce the influence of different breeds and gender. This study was conducted on nine Thoroughbred horses ( 2 geldings, 7 stallions) aged $8.9 \pm 2.2$ (mean \pm standard deviation) years and seven Croatian Warmblood horses (4 geldings, 3 stallions) aged $9.3 \pm 2.9$ years were monitored during and after their preparations for the Alka jousting competition. All the selected 
animals were of mild temper, and all the selected animals were geldings. They were kept under the same housing and feeding conditions from mid March to mid August. During the training and preparations they were fed three times a day according to the following schedule: $3 \mathrm{~kg}$ hay, $2 \mathrm{~kg}$ oats at 8 a.m., $2 \mathrm{~kg}$ hay at $1 \mathrm{p} . \mathrm{m}$. and $3 \mathrm{~kg}$ hay, 2-3 kg oats at 9 p.m. Water and licking salt (Biosaxon, Solinen, Austria) were available ad libitum.

Training programme. The horses were trained in the period from May to June using a combined conditioning program consisting of $20 \%$ gallop, $50 \%$ canter and $30 \%$ walking for 120 minutes. In the first two weeks of July the horses underwent speed trainings lasting 60 minutes, which included 3 high speed gallop bouts on a racecourse $200 \mathrm{~m}$ long. In the last two weeks of July the horses were brought to the Alka course where they could adapt to the surroundings, including loud music, crowds of people and a walk through the town, together with 3 fast gallops on the $160 \mathrm{~m}$ long course. The horses were expected to carry approx. $130 \mathrm{~kg}$ (the rider and equipment) on a ceremonial walk through the town, and run at a gallop on the $160 \mathrm{~m}$ long course.

Blood sampling. Blood was sampled five times: 30 days before the race, that is at the start of speed training, 21 days before the race in the middle of speed training, two weeks before the race (at the end of speed training), immediately after the race, and finally after 7 days of rest.

Blood samples were collected from the jugular vein into a BD Vacutainer SST (Plymouth, UK), at a time between 8:00-8:30 p.m. during first three samplings and last venepuncture. Samples were centrifuged immediately at $1500 \mathrm{~g}$ for $15 \mathrm{~min}$ at $20{ }^{\circ} \mathrm{C}$ and kept frozen at $-80{ }^{\circ} \mathrm{C}$ until analysis.

Antioxidative enzyme assays. Glutathione peroxidase (GSH-Px) and superoxide dismutase (SOD) serum activities were assayed on an Olympus AU 400 (Olympus, Japan) biochemical analyzer, using the commercial Ransel and Ransod reagent kits (both Randox, Crumlin, UK), respectively.

Paraoxonase 1 activity in the serum was assayed by hydrolysis of paraoxon using a modified method described by CHARLTON-MENYS et al. (2006) also on an Olympus AU 400 (Olympus, Japan). Enzyme activity was presented in U/L (1 $\mu \mathrm{mol}$ p-nytrophenol formed $/ \mathrm{min} / \mathrm{L}$ serum). The ratio of the PON 1 activity and HDL-C concentration was calculated and expressed as $\mathrm{U} / \mathrm{mmol}$.

Oxidative stress parameter. Serum malondialdehyde (MDA) concentration was measured using high performance liquid chromatography (HPLC) with UV detection, as described by GROTTO et al. (2007) on a TSP-130 system (Thermo Separation Products, Inc, Thermo Fisher Scientific, Inc., Waltham, MA, SAD) with the reversedphase analytical column protected with a guard column (Waters symmetry ${ }^{\circledR} \mathrm{C} 18$ column, $5 \mu \mathrm{m}, 150 \times 4.6 \mathrm{~mm}$ i.d.) maintained at $40{ }^{\circ} \mathrm{C}$. 1,1,3,3-tetraethoxypropane was used for 
calibration (Sigma-Aldrich Chemie GmbH, Taufkirchen, Germany). The mobile phase was a mix of $50 \mathrm{mM}$ phosphate buffer and methanol $(50: 50, \mathrm{v} / \mathrm{v})$, and the flow rate was maintained isocratically at $1 \mathrm{~mL} / \mathrm{min}$. The UV was programmed at $532 \mathrm{~nm}$. The retention time was $2.9 \mathrm{~min}$. Samples were prepared for analysis as described previously (GROTTO et al., 2007).

Muscle enzyme activities. The activities of the serum enzymes, aspartate aminotransferase (AST), creatine kinase (CK) and lactate dehydrogenase (LDH), were also assayed. Muscle enzymes' activities were determined using a SABA (AMS, Rome, Italy) biochemical analyser according to the manufacturer's protocol. Reagents were supplied by Herbos dijagnostika d.o.o. (Sisak, Croatia).

Metabolic parameters concentrations. Serum metabolic parameters glucose, triglycerides, nonesterified fatty acids (NEFA), total cholesterol and high-density lipoprotein cholesterol (HDL-C) were measured. Analyses were performed using a SABA (AMS, Rome, Italy) biochemical analyzer according to the manufacturer's protocol. Reagents were supplied by Herbos dijagnostika d.o.o. (Sisak, Croatia).

Statistical analysis. The results were statistically processed using Statistica 9 software (StatSoft, USA) and expressed as mean \pm standard deviation (Mean \pm SD). The normality of distribution was checked using Kolmogorov-Smirnov and Shapiro-Wilk's W test. Following variance repeated measures analyses, significant between-breed differences were detected by Tukey's test, where the distribution was normal. The Friedman ANOVA test and Wilcoxon post hoc analysis were employed if the null hypothesis was rejected (PETRIE and WATSON, 2006). Breed differences were tested using the Mann-Whitney $\mathrm{U}$ test. The correlation between the study parameters (Spearman Rank Order Correlations or Pearson correlation coefficient) was tested using the same statistical software. The level of statistical significance was set at $\mathrm{P}<0.05$.

\section{Results}

Table 1 shows serum antioxidative enzymes activities and PON1/HDL-C ratios in both groups. Serum SOD activity in Thoroughbred horses (TH) was significantly higher 21 days before the Alka competition compared to the values after the rest $(\mathrm{P}<0.05)$. Glutathione peroxidase and PON 1 activities, as well as PON1/HDL-C ratio did not change significantly during the experiment. The PON1/HDL-C ratio was significantly higher in Croatian Warmblood horses $(\mathrm{CWH})$ than in TH serum 21 days before the Alka $(\mathrm{P}<0.05)$. The highest MDA serum concentration was found 30 days before the Alka in both breeds. For TH, those values were significantly higher than those found during the Alka competition $(\mathrm{P}<0.05)$. For $\mathrm{CWH}$, they were higher than all the other MDA values found during the experiment $(\mathrm{P}<0.05)$. MDA values were significantly lower in $\mathrm{CWH}$ than in TH 14 days before the Alka (Table 1; $\mathrm{P}<0.05$ ). 
Table 1. Serum antioxidative enzyme activities and MDA concentrations in Thoroughbred (TH) and Croatian Warmblood $(\mathrm{CWH})$ horses $($ Mean $\pm \mathrm{SD})$

\begin{tabular}{|c|c|c|c|c|c|}
\hline & \multicolumn{5}{|c|}{ Sampling stages } \\
\hline & \multicolumn{3}{|c|}{ Days before the Alka } & \multirow{2}{*}{$\begin{array}{c}\begin{array}{c}\text { The Alka } \\
\text { (competition) }\end{array} \\
0 \\
0\end{array}$} & \multirow{2}{*}{$\begin{array}{c}\text { Days after the } \\
\text { Alka } \\
7\end{array}$} \\
\hline & 30 & 21 & 14 & & \\
\hline \multicolumn{6}{|c|}{ Glutathione peroxidase (U/L) } \\
\hline $\mathrm{TH}$ & $719 \pm 135$ & $785 \pm 110$ & $837 \pm 68$ & $799 \pm 89$ & $735 \pm 183$ \\
\hline $\mathrm{CWH}$ & $691 \pm 132$ & $773 \pm 95$ & $779 \pm 1$ & $652 \pm 266$ & $699 \pm 180$ \\
\hline \multicolumn{6}{|c|}{ Superoxide dismutase (U/L) } \\
\hline TH & $106 \pm 12^{\mathrm{ab}}$ & $126 \pm 7^{a}$ & $118 \pm 19^{\mathrm{ab}}$ & $111 \pm 12^{\mathrm{ab}}$ & $97 \pm 14^{\mathrm{b}}$ \\
\hline $\mathrm{CWH}$ & $106 \pm 17$ & $122 \pm 19$ & $122 \pm 17$ & $119 \pm 13$ & $94 \pm 14$ \\
\hline \multicolumn{6}{|c|}{ Paraoxonase $1(\mathrm{U} / \mathrm{L})$} \\
\hline TH & $374 \pm 110$ & $329 \pm 18$ & $325 \pm 43$ & $376 \pm 84$ & $319 \pm 93$ \\
\hline $\mathrm{CWH}$ & $317 \pm 37$ & $334 \pm 45$ & $419 \pm 175$ & $339 \pm 19$ & $304 \pm 35$ \\
\hline \multicolumn{6}{|c|}{ Paraoxonase $1 /$ high density lipoprotein-cholesterol ratio (U/mmol) } \\
\hline TH & $297 \pm 117$ & $238 \pm 50$ & $276 \pm 58$ & $301 \pm 53$ & $280 \pm 63$ \\
\hline $\mathrm{CWH}$ & $275 \pm 71$ & $307 \pm 16^{*}$ & $294 \pm 111$ & $298 \pm 49$ & $285 \pm 43$ \\
\hline \multicolumn{6}{|c|}{ Malondialdehyde $(\mu \mathrm{mol} / \mathrm{L})$} \\
\hline TH & $6.73 \pm 0.45^{b}$ & $6.03 \pm 0.50^{\mathrm{ab}}$ & $6.32 \pm 0.36^{\mathrm{ab}}$ & $5.69 \pm 0.37^{\mathrm{a}}$ & $6.34 \pm 0.56^{\mathrm{ab}}$ \\
\hline $\mathrm{CWH}$ & $6.85 \pm 0.15^{\mathrm{a}}$ & $5.85 \pm 0.17^{\mathrm{b}}$ & $4.95 \pm 0.08^{\mathrm{b} *}$ & $5.76 \pm 0.38^{\mathrm{b}}$ & $5.83 \pm 0.37^{\mathrm{b}}$ \\
\hline
\end{tabular}

a, b - within rows, means followed by different letters are significantly different $(\mathrm{P}<0.05)$. * - significant differences between breeds $(\mathrm{P}<0.05)$

Serum muscle enzyme activities did not change significantly during the course of the experiment within the groups (Table 2). CWH had significantly higher values of AST and CK 30 days before the Alka and CK 21 days before the Alka compared to TH $(\mathrm{P}<0.05)$. Serum LDH activities did not differ significantly between TH and CWH.

Serum concentrations of metabolic parameters are shown in Table 3. Triglyceride concentrations in $\mathrm{TH}$ were significantly higher 30 days before the Alka when compared to values 14 days before $(\mathrm{P}<0.05)$. Furthermore, triglyceride was significantly higher after 7 days of rest when compared to concentrations immediately after the race $(\mathrm{P}<0.05)$. The highest NEFA concentrations in TH were found 30 days before the competition. Those values, as well as those immediately after the race, were significantly higher than after 7 days' rest $(\mathrm{P}<0.05)$. Regarding breed differences, $\mathrm{CWH}$ had significantly higher triglyceride concentrations than TH 21 days before the race $(\mathrm{P}<0.05)$. No significant 
differences in glucose, total cholesterol and HDL-C concentrations were found regarding the research periods or breed.

Table 2. Muscle enzymes activity in Thoroughbred (TH) and Croatian Warmblood (CWH) horses $($ Mean \pm SD)

\begin{tabular}{|c|c|c|c|c|c|}
\hline & \multicolumn{5}{|c|}{ Sampling stages } \\
\hline & \multicolumn{3}{|c|}{ Days before the Alka } & $\begin{array}{l}\text { The Alka } \\
\text { (competition) }\end{array}$ & $\begin{array}{c}\text { Days after the } \\
\text { Alka }\end{array}$ \\
\hline & 30 & 21 & 14 & 0 & 7 \\
\hline \multicolumn{6}{|c|}{ Aspartate aminotransferase (U/L) } \\
\hline TH & $286 \pm 18$ & $326 \pm 74$ & $294 \pm 36$ & $302 \pm 51$ & $305 \pm 64$ \\
\hline $\mathrm{CWH}$ & $334 \pm 11 *$ & $369 \pm 28$ & $369 \pm 109$ & $357 \pm 58$ & $275 \pm 37$ \\
\hline \multicolumn{6}{|c|}{ Creatine kinase (U/L) } \\
\hline TH & $167 \pm 22$ & $176 \pm 34$ & $175 \pm 26$ & $135 \pm 26$ & $135 \pm 32$ \\
\hline $\mathrm{CWH}$ & $221 \pm 8^{*}$ & $468 \pm 195^{*}$ & $308 \pm 209$ & $124 \pm 18$ & $99 \pm 30$ \\
\hline \multicolumn{6}{|c|}{ Lactate dehydogenase (U/L) } \\
\hline $\mathrm{TH}$ & $289 \pm 53$ & $349 \pm 61$ & $322 \pm 75$ & $287 \pm 77$ & $256 \pm 110$ \\
\hline CWH & $298 \pm 37$ & $383 \pm 38$ & $356 \pm 23$ & $354 \pm 89$ & $208 \pm 24$ \\
\hline
\end{tabular}

* - significant differences between breeds $(\mathrm{P}<0.05)$

Table 3. Metabolic parameters concentrations in Thoroughbred (TH) and Croatian Warmblood $(\mathrm{CWH})$ horses $($ Mean $\pm \mathrm{SD})$

\begin{tabular}{|c|c|c|c|c|c|}
\hline & \multicolumn{5}{|c|}{ Sampling stages } \\
\hline & \multicolumn{3}{|c|}{ Days before the Alka } & $\begin{array}{c}\text { The Alka } \\
\text { (competition) }\end{array}$ & $\begin{array}{c}\text { Days after the } \\
\text { Alka }\end{array}$ \\
\hline & 30 & 21 & 14 & 0 & 7 \\
\hline \multicolumn{6}{|c|}{ Glucose (mmol/L) } \\
\hline TH & $5.82 \pm 0.15$ & $4.88 \pm 0.45$ & $5.29 \pm 0.44$ & $5.16 \pm 0.36$ & $5.34 \pm 0.24$ \\
\hline $\mathrm{CWH}$ & $6.21 \pm 0.18$ & $5.67 \pm 1.7$ & $4.57 \pm 0.35$ & $5.31 \pm 0.16$ & $5.59 \pm 0.26$ \\
\hline \multicolumn{6}{|c|}{ Triglycerides $(\mathrm{mmol} / \mathrm{L})$} \\
\hline TH & $0.27 \pm 0.12^{\mathrm{ac}}$ & $0.22 \pm 0.05^{\mathrm{abc}}$ & $0.23 \pm 0.07^{\mathrm{b}}$ & $0.20 \pm 0.04^{\mathrm{abc}}$ & $0.31 \pm 0.07^{\mathrm{c}}$ \\
\hline $\mathrm{CWH}$ & $0.28 \pm 0.02$ & $0.31 \pm 0.02 *$ & $0.13 \pm 0.03$ & $0.18 \pm 0.01$ & $0.24 \pm 0.07$ \\
\hline \multicolumn{6}{|c|}{ Nonesterified fatty acids $(\mathrm{mmol} / \mathrm{L})$} \\
\hline TH & $0.20 \pm 0.09^{\mathrm{a}}$ & $0.15 \pm 0.11^{\mathrm{ab}}$ & $0.06 \pm 0.02^{\mathrm{ab}}$ & $0.19 \pm 0.10^{\mathrm{a}}$ & $0.06 \pm 0.02^{\mathrm{b}}$ \\
\hline $\mathrm{CWH}$ & $0.17 \pm 0.09$ & $0.10 \pm 0.09$ & $0.20 \pm 0.06$ & $0.26 \pm 0.18$ & $0.07 \pm 0.02$ \\
\hline
\end{tabular}


Table 3. Metabolic parameters concentrations in Thoroughbred (TH) and Croatian Warmblood $(\mathrm{CWH})$ horses $($ Mean $\pm \mathrm{SD})$ (continued)

\begin{tabular}{|c|c|c|c|c|c|}
\hline & \multicolumn{5}{|c|}{ Sampling stages } \\
\hline & \multicolumn{3}{|c|}{ Days before the Alka } & $\begin{array}{c}\text { The Alka } \\
\text { (competition) }\end{array}$ & $\begin{array}{c}\text { Days after the } \\
\text { Alka }\end{array}$ \\
\hline & 30 & 21 & 14 & 0 & 7 \\
\hline \multicolumn{6}{|c|}{ Total cholesterol $(\mathrm{mmol} / \mathrm{L})$} \\
\hline TH & $2.33 \pm 0.30$ & $2.27 \pm 0.18$ & $2.29 \pm 0.33$ & $2.59 \pm 0.42$ & $2.21 \pm 0.13$ \\
\hline $\mathrm{CWH}$ & $2.03 \pm 0.24$ & $2.23 \pm 0.63$ & $2.62 \pm 0.36$ & $2.26 \pm 0.25$ & $2.23 \pm 0.32$ \\
\hline \multicolumn{6}{|c|}{ High density lipoprotein-cholesterol (mmol/L) } \\
\hline TH & $1.29 \pm 0.20$ & $1.44 \pm 0.33$ & $1.20 \pm 0.20$ & $1.24 \pm 0.14$ & $1.19 \pm 0.06$ \\
\hline CWH & $1.15 \pm 0.18$ & $1.09 \pm 0.14$ & $1.41 \pm 0.06$ & $1.16 \pm 0.20$ & $1.08 \pm 0.12$ \\
\hline
\end{tabular}

a,b,c - within rows, means followed by different letters are significantly different $(\mathrm{P}<0.05) .{ }^{*}$ - significant differences between breeds $(\mathrm{P}<0.05)$

Table 4. Correlations of serum parameters in Thoroughbred (TH) and Croatian Warmblood (CWH) horses

\begin{tabular}{|l|c|}
\hline Serum parameters & $\begin{array}{c}\text { Correlation coefficient; } \\
\text { level of significance }\end{array}$ \\
\hline TH & $0.4507 ; \mathrm{P}<0.05$ \\
\hline Paraoxonase 1 : Glutathione peroxidase & $0.4626 ; \mathrm{P}<0.05$ \\
\hline Glutathione peroxidase : Paraoxonase 1/ HDL-C ratio & $0.4247 ; \mathrm{P}<0.05$ \\
\hline Aspartate aminotransferase : Creatine kinase & $0.4924 ; \mathrm{P}<0.05$ \\
\hline Creatine kinase : Lactate dehydogenase & \\
\hline CWH & $0.5033 ; \mathrm{P}<0.05$ \\
\hline Superoxide dismutase : Glutathione peroxidase & $-0.4457 ; \mathrm{P}<0.05$ \\
\hline Glutathione peroxidase : Malondialdehyde & $0.7115 ; \mathrm{P}<0.05$ \\
\hline Aspartate aminotransferase : Creatine kinase & $0.6973 ; \mathrm{P}<0.05$ \\
\hline Creatine kinase : Lactate dehydogenase & $0.8165 ; \mathrm{P}<0.05$ \\
\hline Aspartate aminotransferase : Lactate dehydogenase & $0.5532 ; \mathrm{P}<0.05$ \\
\hline Nonesterified fatty acids : High density lipoprotein-cholesterol & \\
\hline
\end{tabular}

In TH significant correlations were found between PON 1 and GSH-Px $(\mathrm{P}<0.05)$. In our study, a significant correlation was recorded between GSH-Px and PON 1/HDL-C ratio, AST and $\mathrm{CK}$ and $\mathrm{LDH}$ in $\mathrm{TH}(\mathrm{P}<0.05$; Table 4). Samples obtained from $\mathrm{CWH}$ showed a significant correlation between GSH-Px and SOD and MDA, as well as AST 
and $\mathrm{CK}$ and $\mathrm{AST}$ and $\mathrm{LDH}(\mathrm{P}<0.05)$. Also, a significant correlation was noticed between $\mathrm{CK}$ and LDH and NEFA and HDL-C in CWH $(\mathrm{P}<0.05$; Table 4).

\section{Discussion}

In this research we have changes in SOD activity, MDA, NEFA, and triglyceride concentrations in TH serum, as well as breed differences with $\mathrm{CWH}$ regarding AST and $\mathrm{CK}$ activity, MDA and triglyceride concentrations and PON 1/HDL-C ratio, during training and the Alka competition.

Exercise induces oxidative stress in both animals and people, and can lead to some muscle damage (SOFFLER, 2007; POWERS and JACKSON, 2008; STEINBACHER and ECKL, 2015). It is known that training enhances antioxidative capacity, which enables more stability towards lipid peroxidation (HARGREAVES et al., 2002; GONDIM et al., 2009). Antioxidative defences consist of SOD, GSH-Px, PON 1 and catalase activities as well as other non-enzymatic antioxidative compounds (HALLIWELL and GUTTERIDGE, 1999). Enzyme SOD catalyses the dismutation of superoxide radical to hydrogen peroxide which is then removed by GSH-Px. The correlation between the activities of these two enzymes is confirmed by their high correlation found in the CWH in this study (Table 4).

Higher SOD activity was found in $\mathrm{TH}$ in the middle of speed training compared to the resting values. The temporary increase in SOD activity could denote oxidative stress, but the length and intensity of the training prepared the horses well for the stress of the competition. SOARES et al. (2011) found increased SOD activity in horse erythrocytes $24 \mathrm{hrs}$ after rest, while the lowest SOD activity in this study was found after 7 days' rest.

Glutathione peroxidase and PON 1 remove lipid peroxides and consequently reduce oxidative damage to lipids, as well as propagating peroxidation towards other molecules (HALLIWELL and GUTTERIDGE, 1999). Serum GSH-Px activity was not significantly altered in the groups during the research. KIRSCHVINK et al. (2008) found a significant increase in GSH-Px activity during exercise, as did HARGREAVES et al. (2002). The lack of changes in GSH-Px activity in this study could be attributed to prolonged training that may have elevated other antioxidative components. It could also be due to the pronounced breed-specific ability for adaptation to elevated oxygen consumption (ART and LEKEUX, 2005). Antioxidative status depends on breed, age and sex, as seen in KIRSCHVINK et al. (2006), who found breed differences for GSH-Px activities. This study included horses of similar age and temperament, of two different breeds, but no breed effect was established.

Paraoxonase 1 is an antioxidative enzyme associated with high density lipoproteins. Its activity is reduced in untrained individuals (TOMÁS et al., 2002), and balanced in athletes (BENÍTEZ et al., 2002). Regular aerobic training enhances the antioxidative 
properties of HDL and contributes to oxidative stress adaptation in athletes (BRITES et al., 2006). We found no significant differences between PON 1 activities during training and the race, which may be ascribed to appropriate training. The antioxidative role of PON 1 is further confirmed by the positive correlation with GSH-Px, as well as GSH-Px with the PON 1/HDL-C ratio found in TH (Table 4).

The malondialdehyde concentrations found in this study were lower during training and the race compared to values after rest in both breeds. Breed specific differences were found: CWH had lower MDA concentrations than TH 14 days before the Alka. Lower lipid peroxidation intensity was found after exercise in humans (PEPE et al., 2009) and horses (CHIARADIA et al., 1998). SOARES et al. (2011) found elevated lipid peroxides after a race, but in horse erythrocytes, while ISHIDA et al. (1999) determined higher lipid peroxide levels in equine serum. In the present study, we found a negative correlation between GSH-Px and MDA (Table 4), so that the lower MDA concentrations could be ascribed to GSH-Px mediated peroxide removal.

The adaptation of muscle fibres is proportional to their load during exercise (RIVERO et al., 2007). Exercise induced oxidative stress is accompanied by changes in myocyte specific enzyme activity. Enhanced peroxidation of sarcolemma can result in its increased permeability, enzyme leakage and subsequent elevated enzymatic activity in the blood (SOFFLER, 2007). Enzymes, CK, LDH and AST serum activities are considered to be the main indicators of myocyte stability. BOFFI et al. (2002) found significantly higher blood CK activities in trained horses. Higher levels of CK and AST were found after endurance exercise (HARGREAVES et al., 2002) as well as after short, high intensity exercise (SICILIANO et al., 1995). Likewise, CHIARADIA et al. (1998) found no change in $\mathrm{CK}$ and $\mathrm{LDH}$ activities during training, probably due to myocyte adaptation.

The activity of CK did not change significantly in this study. However, we found breedspecific differences 30 and 21 days before the race, attributable to specific adaptations in training. Elevated CK activity during training is probably a consequence of a temporary increase in sarcolemma permeability (KERKSICK and WILLOUGHBY, 2005).

Serum LDH activity was constant in both breeds during the research, but twice as high as the reference values for horses (VALBERG, 2006) which is in accordance with results in athletes (BRITES et al., 2006). Besides their use as myocyte damage indicators, it is important to observe the mutual relationships of AST, LDH and CK. We found positive correlations between these enzymes' activities in both breeds. In TH we found correlations between CK and AST, and CK and LDH activity (Table 4). In CWH we found correlations between CK and AST; CK and LDH, as well as AST and LDH activity (Table 4). MARLIN et al. (2002), in contrast to these results, found no correlation between AST and CK activity in horses after long and intensive training, but it is important to repeat that enzyme activity depends on both the duration and design of the training. 
The utilisation of lipids in racehorse muscles is enhanced for the purposes of energy formation. That process increases fat mobilisation (LI et al., 2012; POOLE and ERICKSON, 2015). Intensive training enhances NEFA, triglyceride and total cholesterol blood concentrations, as a consequence of various adapting processes (LI et al., 2012). Muscle glycogen reserves are lower during exercise, whereas NEFA concentrations rise in line with muscle fatigue (BENÍTEZ et al., 2002). Serum NEFA concentrations were significantly higher at the beginning of this study than the final values 7 days after the race. There were no significant changes to NEFA in CWH blood during the experiment, but we found significant correlations between NEFA and HDL-C (Table 4), HDL-C being a significant transporter of NEFA towards the liver (BENÍTEZ et al., 2002). ZIMMERMAN et al. (1992) found a significant serum NEFA increase in horses after training, which decreased after rest, as seen in this research.

There were significant changes in triglyceride concentrations during our study. During speed training triglyceride levels dropped, probably due to their utilisation for energy requirements. After the rest, their concentrations went back to the baseline values. A significant difference was found between breeds 21 days before the race, where $\mathrm{CWH}$ had higher triglyceride values.

Unlike MUÑOZ et al. (2002), we found no significant breed differences for glucose concentrations. It seems that the training duration and design used in this research could have provided enough time for both lipid metabolism and liver normoglycemic function to adapt to enhanced energy requirements (POOLE and ERICKSON, 2015).

The results show that the increase in SOD activity in $\mathrm{TH}$ in the middle of speed training could imply oxidative stress, however the unchanged GSH-Px and PON 1 activities in both groups during speed training point to appropriate training regimes. Higher AST and CK levels in CWH at the beginning of this research, as well as CK activity during training, show breed-specific differences in the adaptive process. The higher serum NEFA concentrations in TH found in the beginning of the experiment, and the lower triglyceride concentrations during training show a significant shift in fat metabolism due to the elevated energy needs.

\section{Sources of funding}

This research was supported by a grant from the Ministry of Science, Education and Sports, Croatia (No. 0530532053-2051).

\section{References}

ART, T., P. LEKEUX (2005): Exercise-induced physiological adjustments to stressful conditions in sports horses. Livest. Prod. Sci. 92, 101-111. 
AYALA, A., M. F. MUÑOZ, S. ARGÜELLES (2014): Lipid peroxidation: production, metabolism, and signaling mechanisms of malondialdehyde and 4-hydroxy-2-nonenal. Oxid. Med. Cell Longev. Article ID 360438, 31 pages.

BENÍTEZ, S., J. L. SÁNCHEZ-QUESADA, L. LUCERO (2002): Changes in low-density lipoprotein electronegativity and oxidizability after aerobic exercise are related to the increase in associated non-esterified fatty acids. Atherosclerosis 16, 223-232.

BOFFI, F. M., J. CITTAR, G. BALSKUS, M. MURIEL, E. DESMARAS (2002): Training-induced apoptosis in skeletal muscle. Equine Vet. J. 34, 275S-278S.

BRITES, F., V. ZAGO, J. VERONA, M. L. MUZZIO, R. WIKINSKI, L. SCHREIER (2006): HDL capacity to inhibit LDL oxidation in well-trained triathletes. Life Sci. 78, 3074-3081.

CHARLTON-MENYS, V., Y. LIU, P. N. DURRINGTON (2006): Semiautomated method for determination of serum paraoxonase activity using paraoxon as substrate. Clin. Chem. 52, 453-457.

CHIARADIA, E., L. AVELLINI, F. RUECA, A. SPATERNA, F. PORCIELLO, M. T. ANTONIONI, A. GAITI (1998): Physical exercise, oxidative stress and muscle damage in racehorses. Comp. Biochem. Physiol. Part B 119, 833-836.

DI MEO, S., P. VENDITTI (2001): Mitochondria in exercise-induced oxidative stress. Biol. Signal Recep. 10, 125-140.

GONDIM, F. J., C. C. ZOPPI, L. R. SILVEIRA, L. PEREIRA-DA-SILVA, D. V. DE MACEDO (2009): Possible relationship between performance and oxidative stress in endurance horses. J. Equine Vet. Sci. 29, 206-212.

GROTTO, D., L. D. SANTA MARIA, S. BOEIRA (2007): Rapid quantification of malondialdehyde in plasma by high performance liquid chromatography-visible detection. J. Pharmaceut. Biomed. 43, 619-624.

GUYTON, A. C., J. E. HALL (2016): Sports Physiology. In: Textbook of Medical Physiology. (Guyton, A. C., J. E. Hall, Eds.), Elsevier Saunders, Philadelphia, Pennsylvania, USA, pp 1085-1095.

HALliWELL, B., J. M. C. GUTTERIDGE (1999): Antioxidant defences. In: Free Radicals in Biology and Medicine. (Halliwell, B., J. M. C. Gutteridge, Eds.), Oxford University Press, New York, USA, pp. 105-148.

HARGREAVES, B. J., D. S. KRONFELD, J. N. WALDRON, M. A. LOPES, L. S. GAY, K. E. SAKER, W. L. COOPER, D. J. SKLAN, P. A. HARRIS (2002): Antioxidant status and muscle cell leakage during endurance exercise. Equine Vet. J. 34, 116S-121S.

ISHIDA, N., S. HOBO, T. TAKAHASHI, Y. NANBO, F. SATO, T. HASEGAWA, H. MUKOYAMA (1999): Chronological changes in superoxide-scavenging ability and lipid peroxide concentration of equine serum due to stress from exercise and transport. Equine Vet. J. 30, 430S-433S.

KERKSICK, C., D. WILlOUGHBY (2005): Cysteine Supplements and Exercise-Induced Oxidative Stress. J. Int. Soc. Sports Nutr. 2, 38-44. 
KIRSCHVINK, N., B. DE MOFFARTS, F. FARNIR, J. PINCEMAIL, P. LEKEUX (2006): Investigation of blood oxidant/antioxidant markers in healthy competition horses of different breeds. Equine Vet. J. 36, 239S-244S.

KIRSCHVINK, N., B. MOFFARTS, P. LEKEUX (2008): The oxidant/antioxidant equilibrium in horses. Vet. J. 177, 178-191.

LI, G., P. LEE, N. MORI, I. YAMAMOTO, T. ARAI (2012): Long term intensive exercise training leads to a higher plasma malate/lactate dehydrogenase $(\mathrm{M} / \mathrm{L})$ ratio and increased level of lipid mobilization in horses. Vet. Res. Commun. 36, 149-155.

LI, LJ. (2008): Modulation of skeletal muscle antioxidant defense by exercise: Role of redox signaling. Free Rad. Biol. Med. 44, 142-152.

MARLIN, D. J., K. FENN, N. SMITH, C. D. DEATON, C. A. ROBERTS, P. A. HARRIS, C. DUNSTER, F. J. KELLY (2002): Changes in circulatory antioxidant status in horses during prolonged exercise. J. Nutr. 132, 1622S-1627S.

MUÑOZ, A., C. RIBER, R. SANTISTEBAN, R. G. LUCAS, F. M. CASTEJÓN (2002): Effect of training duration and exercise on blood-borne substrates, plasma lactate and enzyme concentrations in Andalusian, Anglo-Arabian and Arabian breeds. Equine Vet. J. 34, 245S-251S.

PEPE, H., S. S. BALC, S. REVAN, P. P. AKALM, F. KURTOĞLU (2009): Comparison of oxidative stress and antioxidant capacity before and after running exercises in both sexes. Gender Med. 6, 587-95.

PETRIE, A., P. WATSON (2006): Statistics for veterinary and animal science. In: Statistics for veterinary and animal science. (Petrie, A., P. Watson, Eds.), Blackwell Publiching, Oxford, UK, pp. 166-168.

POOLE, D. C., H. H. ERICKSON (2015): Exercise physiology of terrestrial animals. In: Dukes' Physiology of Domestic Animals. (Reece, W. O, Ed.), Wiley Blackwell, Oxford UK pp. 457459.

POWERS, S. K., M. J. JACKSON (2008): Exercise-induced oxidative stress: cellular mechanisms and impact on muscle force production. Physiol. Rev. 88, 1243-76.

RIVERO, J. L., A. RUZ, S. MARTÍ-KORFF (2007): Effects of intensity and duration of exercise on muscular responses to training of Thoroughbred racehorses. J. Appl. Physiol. 102, 1871-1882.

SICILIANO, P. D., L. M. LAWRENCE, K. DANIELSEN, D. M. POWELL, K. N. THOMPSON (1995): Effect of conditioning and exercise type on serum creatine kinase and aspartate aminotransferase activity. Equine Vet. J. 18, 243S-247S.

SOARES, J. C. M., R. ZANELLA, C. BONDAN (2011): Biochemical and antioxidant changes in plasma, serum, and erythrocytes of horses before and after a jumping competition. J. Equine Vet. Sci. 31, 357-360.

SOFFLER, C. (2007): Oxidative stress. Vet. Clin. N. Am-Equine 23, 135-157.

STEINBACHER, P., P. ECKL (2015): Impact of oxidative stress on exercising skeletal muscle. Biomolecules 5, 356-377. 
TOMÁS, M., R. ELOSUA, M. SENTÍ (2002): Paraoxonase1-192 polymorphism modulates the effects of regular and acute exercise on paraoxonase1 activity. J. Lipid Res. 43, 713-720.

VALBERG, S. J. (2006): Skeletal muscle function. In: Clinical Biochemistry in Domestic Animals. (Valberg, S. J., Ed.), Academic Press, USA, pp. 458-483.

VERMEUleN, R., C. DE MEEÛS, L. PlANCKE, B. BOSHUIZEN, M. DE BRUIJN, C. DELESALLE (2017): Effects of training on equine muscle physiology and muscle adaptations in response to different training approaches. Vlaams Diergeneeskund. Tijdschr. 86, 224-230.

ZIMMERMAN, N. I., S. J. WICKLER, A. V. RODIEK, M. A. HOWER (1992): Free fatty acids in exercising arabian horses fed two common diets. J. Nutr. 122, 145-150.

\section{ALADROVIĆ, J., B. BEER LJUBIĆ. N. PRVANOVIĆC BABIĆ, L. VRANKOVIĆ, E. KLEPO, L. ILIČIĆ, S. S̆IMUNDŽA, L. RADIN, J. ŚURAN, J. KOS, Z. STOJEVIĆ: Utjecaj treninga i alkarskog natjecanja na oksidacijski stres i metaboličke pokazatelje u dvije pasmine konja. Vet. arhiv 88, 295-308, 2018. \\ SAŽETAK}

Cilj ovog istraživanja bio je utvrditi utjecaj treninga i alkarskog natjecanja na aktivnosti/koncentracije antioksidacijskih i mišićnih enzima te metaboličkih pokazatelja u serumu konja. Istraživanje je provedeno na 9 konja pasmine engleski punokrvnjak i na sedam konja pasmine hrvatski toplokrvnjak. Uzorci krvi uzimani su 30, 21 i 14 dana prije alke, neposredno nakon natjecanja te 7 dana nakon natjecanja. Koncentracija malondialdehida (MDA) te aktivnosti enzima glutation-peroksidaze (GSH-Px), ukupne superoksid-dismutaze (SOD), paraoksonaze 1 (PON 1), kreatin-kinaze (CK), aspartat-aminotransferaze (AST) i laktat-dehidrogenaze (LDH) određene su u serumu, kao i koncentracije glukoze, triglicerida, slobodnih masnih kiselina (NEFA), ukupnog kolesterola te kolesterola vezanog na lipoproteine visoke gustoće (HDL-C). Koncentracija MDA u serumu obiju pasmina konja bila je značajno viša 30 dana prije alke u usporedbi s vrijednostima neposredno nakon utrke. Aktivnost SOD-a u serumu engleskih punokrvnjaka bila je značajno viša 21 dan prije alke u usporedbi s aktivnostima 7 dana nakon odmora. Koncentracija NEFA-e u engleskih punokrvnjaka bila je također značajno viša 30 dana prije alke i neposredno nakon utrke u usporedbi s koncentracijom 7 dana nakon utrke. Koncentracija triglicerida u serumu engleskih punokrvnjaka bila je značajno viša nakon odmora u usporedbi s vrijednostima 30 i 14 dana prije utrke. Omjer PON 1/HDL-C bio je značajno viši u serumu hrvatskih toplokrvnjaka u usporedbi s engleskim punokrvnjacima 21 dan prije alke. Koncentracija MDA bila je značajno niža u serumu hrvatskih toplokrvnjaka u odnosu na engleske punokrvnjake 14 dana prije alke. Utvrđene su značajno više aktivnosti AST-a i CK u hrvatskih toplokrvnjaka u usporedbi s aktivnostima u engleskih punokrvnjaka 30 dana prije Alke. Koncentracija triglicerida 21 dan prije utrke bila je značajno viša $\mathrm{u}$ hrvatskih toplokrvnjaka u uporedbi s vrijednostima u engleskih punokrvnjaka. Rezultati ovog istraživanja upućuju na oksidacijsku stabilnost seruma konja tijekom treninga i utrke, pasminske razlike tijekom treninga i natjecanja te promjenu energetskog metabolizma u smjeru lipolize zbog povećanih energetskih potreba konja.

Ključne riječi: konji; trening; antioksidativni enzimi; oksidacijski stres; metabolički pokazatelji 